\title{
SOCIAL RESPONSIBILITY, A KEY DIMENSION IN DEVELOPING A SUSTAINABLE HIGHER EDUCATION INSTITUTION: THE GASE OF STUDENTS' MOTIVATION
}

\author{
Cosmin-Ionuț Imbrișcă ${ }^{1 *}$ and Sorin-George Toma ${ }^{2}$ \\ ${ }^{1,2)}$ University of Bucharest, Romania
}

Please cite this article as:

Imbrișcă, C.I. and Toma, S.G., 2020. Social Responsibility, a Key Dimension in Developing a Sustainable Higher Education Institution: The Case of Students' Motivation. Amfiteatru Economic, 22(54), pp. 447-461.

DOI: $10.24818 / \mathrm{EA} / 2020 / 54 / 447$

Article History

Received: 30 December 2019

Revised: 30 January 2020

Accepted: 5 March 2020

\begin{abstract}
Over time, sustainability and social responsibility have become key concepts at macrolevel, meso-level and micro-level, and in various domains such as business and higher education. The paper aims to explain the close relationship between the two concepts in higher education, and to identify and analyse the various factors that motivate or impede students from becoming involved in social responsibility activities. The information was gathered by using a stratified sampling method from the students enrolled at a Romanian higher education institution, the Faculty of Business and Administration University of Bucharest. Then, the information was processed through the factorial analysis in order to identify the underlying unobserved variables and how they relate to students' decision to participate in social responsibility activities. Finally, a logit regression analysis led to the main results that show that personal values are the main motivators, whereas structural and interpersonal barriers are the main inhibitors. The paper also demonstrates that the social responsibility activities contribute to the development of sustainable higher education institutions through the active engagement and participation of their students.
\end{abstract}

Keywords: sustainability, social responsibility, sustainable higher education institution, students, motivation, sustainable development.

JEL Classification: M14, Q56.

* Corresponding author, Cosmin-Ionuț Imbrișcă - cosmin.imbrisca@ faa.unibuc.ro 


\section{Introduction}

From the beginning of the 1970s, significant events and actions, carried on at national, regional and international levels, have paved the way for the emergence and expansion of the concepts of sustainability and sustainable development (SD), both in theory and practice. As the world's oldest global environmental organization, the International Union for the Conservation of Nature and Natural Resources (IUCN) was deeply involved in the preparations of the United Nations (UN) Conference on the Human Environment, held in Stockholm in 1972. It was for the first time in the post-war period when the issue of sustainability was discussed at a global level.

In 1987, the Brundtland Commission defined SD as "development that meets the needs of the present without compromising the ability of future generations to meet their own needs" (World Commission Environment and Development, 1987, p.43). The number of international agreements and conferences on SD grew exponentially in the following decades. All of these (e.g., the 2015 UN Summit on SD) constituted major events that put accent on the need of a holistic approach of SD that integrates all its dimensions- social, economic and environmental- and their interconnections (Toma and Grădinaru, 2018). Thus, SD is seen not only as a concept or a policy, but also as a process that tries to mix growing environmental concerns with socio-economic problems (Hopwood, Mellor and O'Brien, 2005) in order to achieve its long-term goal, sustainability (da Silva Junior et al., 2019).

During the time, SD and sustainability have become key themes at macro-level (e.g., economy), meso-level (e.g., industry) and micro-level (e.g., organization), and in various domains such as business and higher education (HE). Therefore, an appreciable amount of research devoted to corporate sustainability and its related concepts (e.g., corporate social responsibility, environmental performance) have been published since the 1950s as the evolving societal demands have imposed corporations to take into account the issues of ethics, social responsibility (SR) and sustainability. As HE institutions (HEIs) have also faced the increasing challenge of sustainability, they began to introduce in their curricula courses in business ethics and corporate social responsibility during the 1960s and 1970s (Sharma and Hart, 2014), and later, courses and programs in SD and sustainability. Thus, the education for SD slowly gained acceptance in HE. In time, many HEIs (e.g., universities, faculties) have gradually developed into sustainability incubators (Collins and Gannon, 2014) and became sustainable HEIs. They eventually served as models of sustainability for other organizations by practising sustainability and fully incorporating all its dimensions- economic, social and environmental- in their processes and activities (Cortese, 2003). A particular emphasis was placed on the environmental dimension of sustainability in HE with the launch of the UI Green Metric World University Ranking in 2010, an initiative of Universitas Indonesia (Marrone et al., 2018). This global ranking of universities takes into account several criteria, such as climate change or waste.

The true goal of HE is to prepare its students and/or graduates for life, work and citizenship, to give rise to and form good and engaged citizens (Roosevelt, 2008; Strauss, 2015). Consequently, it is asserted that education, in general, and HE, in particular, fulfil an important social function as they represent "an integral process for the maintenance of a sustainable, vital society" (Simmons, 1986, p.132) and play a critical role in creating a "just and sustainable future" (Cortese, 2003, p.17). This is why increased attention has been shown to the civic engagement and participation of HEIs (Dabija et al., 2017), and 
especially of their main stakeholder- the students-, as they may and should contribute to a more sustainable future of the world (Barth et al., 2016). Moreover, the UN put education, as part of social sustainability, at the heart of its 2030 Agenda for SD, an ambitious plan of action not only for our planet, but also for people and prosperity (UN, 2015). However, most of the studies have focused especially on the environmental dimension of sustainability in HE and neglected its social pillar (Wright, 2007; Arroyo, 2015).

This research is based on the hypothesis that SR contributes to the development of a sustainable HEI. In light of the above discussion, the paper strives to attain the following aims:

- To define the concepts of sustainability, sustainable HEI and SR, and to explain the relationship between sustainability and SR in HE.

- To analyse the students' motivation to engage in SR activities in the case of a Romanian HEI.

In this respect, the information obtained through various research methods (e.g., survey) was gathered, processed and analysed.

The paper is structured as follows. The literature review is presented in the first section of the paper. The second section deals with the research methodology. The results of the research are then analysed and discussed in the third section. Paper ends with conclusions.

\section{Literature review}

In this section, it is accurate to be displayed the theoretical foundation that explains the main concepts of the research and their connection. There is a vast body of literature in the areas of environmental economics, management, business and HE, which defines sustainability, sustainable HEI and SR, and stresses their importance.

Sustainability is ,about building a society in which a proper balance is created between economic, social and ecological aims" (Székely and Knirsch, 2005, p.628) and encompasses "not only aspects such as philanthropy and pollution, but a broad range of social, environmental, and governance performance metrics" (Peloza et al., 1976, p.76). Specifically, sustainability requires "the simultaneous reconciliation of three imperatives: the ecological imperative..., the economic imperative..., the social imperative" (Robinson, 2004, p.381), and, in business, involves "the simultaneous management of three dimensions: profit (economic), people (social), and planet (environmental)" (Montiel and Delgado-Ceballos, 2014, p.113). In sum, the following three dimensions of sustainability were identified (Wanamaker, 2018):

- Environmental sustainability: resource management, habitat restoration \& preservation.

- Economic sustainability: smart growth, long range planning, cost savings, research and development spending, cost of living.

- Social sustainability: quality of life, education, community development, equal opportunity, law \& ethics.

Recent researches have shown that sustainability in HE has been increasingly linked with corporate sustainability due to the multiplication of the interactions among society, businesses and academia (Vargas, Mac-Lean and Huge, 2019). Thus, the conceptualization of sustainability in HE has followed the same pattern: from an 
environmental perspective (Wright, 2010) to a holistic approach (Su and Chang, 2010) that embodies environmental, social and economic dimensions (Wright, 2007). Agostino and Dal Molin (2016) differentiated two main themes debated in the literature:

- the sustainability conceptualization (the "what"), that emphasizes the existence of a loose concept, which refers either to environmental issues or to a broader perspective;

- the sustainability implementation (the "how"), that includes all the needed actions in order to translate sustainability conceptualization into practice, moving from environmental actions (e.g., specific management practices for diminishing environmental impacts) to comprehensive actions (e.g., introduction of courses related to sustainability, SR activities with external stakeholders).

Both themes are heterogeneous due to the existence of various approaches in the world.

Consequently, the definition of a sustainable HEI refers to "environmental, economic and social concerns that universities should have on their activities, and the obligation of "leading by example" (Amaral, Martins and Gouveia, p.157). According to Velazquez et al. (2006, p.812), a sustainable university is "a higher educational institution, as a whole or as a part, that addresses, involves and promotes, on a regional or a global level, the minimization of negative environmental, economic, societal, and health effects generated in the use of their resources in order to fulfil its functions of teaching, research, outreach and partnership, and stewardship in ways to help society make the transition to sustainable lifestyles".

On its turn, the SR of organizations indicates the way they contribute to the well-being of the society and/or community within they operate and expresses the responsibility for the impacts of their activities on society and the environment (ISO, 2010). SR is taken to mean "a balanced approach for organizations to address economic, social and environmental issues in a way that aims to benefit people, communities and society" (IISD, 2004, pp.1-2), being essential for their long-term prosperity (Dinu, 2011). SR is essential for achieving SD in environment and the whole society (Ismail, 2019), and includes various actions and practices, such as the increase of social and environmental awareness through volunteering and investments in local communities.

The above considerations show that there is a close relationship between sustainability and SR in HE. First, both concepts are related to SD. Second, both concentrate on the same dimensions, namely environmental, economic and social. Third, both concepts are associated with "transparency, reputation, consensus and effective monitoring of results, ensuring continuous quality improvements in the university's core business" (Salvioni, Franzoni and Cassano, 2017, p.2). Fourth, SR activities contribute to developing sustainable HEIs as they involve the active engagement and participation of several stakeholders (e.g., students, professors) motivated by various elements such as moral obligations to society and/or community, corporate citizenship and ethical behaviour (Toma, 2008).

\section{Research methodology}

In the first phase, the authors searched for information through a desk research. Numerous secondary data were gathered from electronic databases and libraries. The main sources were journals, books and reports of international organizations. In the second phase, an 
overall profile of the student body enrolled at the Faculty of Administration and Business, University of Bucharest, was constructed. Three reasons explain why this faculty was selected:

- the faculty introduced several courses related to sustainability in its curricula (e.g., Policies for a Sustainable Economy, Business Ethics, Ethics and SR, Volunteering);

- the students and professors have carried out more than 90 SR activities within the students' circle "Business, Ethics and SR" since its founding in 2010;

- the students have been actively involved in numerous environmental activities within the TeamWork Association since its appearance in 2000.

The total population under study counted 1582 students from the undergraduate programs. Because the number of students varies significantly across the different specializations and years of study, a stratified sampling method was used. A representative sample of $25 \%$ of the students from each year of study and specialization was selected, for a rough total of 395.5 respondents, which was rounded up to 400. Overall it was an adequate and proportional representation of all the student body. Students were then chosen randomly and they were handed out questionnaires. The questionnaire was based on the model proposed by Gage and Thapa (2011) which has been also used by other authors in order to measure engagement (Whitley and Yoder, 2015; Jardim and da Silva, 2018; Sloane and Probstl-Haider, 2019). It was adapted by the authors to fit the profile of the Romanian students, with changes such as removing questions regarding home country or ethnicity, or including questions about the university. The survey took place between the $20^{\text {th }}$ of January and the $10^{\text {th }}$ of February 2019 at the faculty. A number of 407 responses was obtained, out of which 10 were discarded, for being incomplete, which resulted in a final sample of 397. Regarding the composition of the sample, the respondents were $67 \%$ female and $33 \%$ male, an expected result as $70 \%$ of the student body enrolled at the faculty is female. Furthermore, $61.21 \%$ of the students were not employed, $18.64 \%$ are employed full-time and the rest part-time. $33.75 \%$ of them have participated in various SR activities in the past 12 months and $56 \%$ of them took part in such activities in high-school. This shows that there already was a propensity towards becoming involved in SR activities. Of those who were involved in SR activities, they worked with a median number of two organisations and an averaged 13.57 hours per week. However, the data was highly skewed with a median of 8 which shows that most of them put in fewer hours than that. Finally, a sense of community seemed to be important to most respondents as $30.48 \%$ identify high-school professors as the reason for getting involved and most took part in humanitarian $(31.23 \%)$, educational $(29.47 \%)$, environmental $(21.16 \%)$, cultural $(14.36 \%)$ or recreational activities and contributed time $(54.41 \%)$ labour $(25.44 \%)$ or money $(22.17 \%)$.

In the third phase, a factorial analysis was computed in order to identify the various motivators and barriers. The newly constructed scales were then used in a series of binary logit models to show to what degree they influence students' decision to participate in SR activities.

\section{Results and discussion}

The study was meant to show why students might become involved in SR activities (motivation) or why they might not (barriers). The questionnaire included scales for values (0.90), self-protection (0.90), social (0.90), career (0.90), and personal enhancement (0.92) 
as motivators for participating in SR activities. It also included structural (0.83), interpersonal $(0.87)$ and intrapersonal $(0.90)$ barriers as reasons for not participating. A series of questions concerning the university, its values (0.93) and opportunities $(0.89)$ were added by the authors. Cronbach's Alpha, as a measure of internal validity, was computed and the values are available in the parentheses. They are all greater than 0.7 which shows they are valid measurements. Each participant was asked to answer, on a scale of 1 to 7, a series of question.

Two more scales were constructed in order to measure whether the university can somehow influence the desire for someone to become involved in SR activities. Of the two scales (table no. 1), one measures the way in which the university values were perceived and a second one to measures whether they considered that they received enough opportunities from the university.

Table no. 1: Factor loadings for university activities

\begin{tabular}{|l|c|c|}
\hline & $\begin{array}{c}\text { University values } \\
\text { and principles }\end{array}$ & $\begin{array}{c}\text { University } \\
\text { opportunities }\end{array}$ \\
\hline Integrity & 0.813 & \\
\hline Efficient communication & 0.895 & \\
\hline Integration and willingness to adapt & 0.869 & \\
\hline Stimulating personal initiatives & 0.823 & \\
\hline Sustainability & 0.828 & \\
\hline Team-spirit & 0.809 & 0.731 \\
\hline Students are given the opportunity to take part in SR activities & & 0.798 \\
\hline The institution encourages SR activities. & & 0.878 \\
\hline $\begin{array}{l}\text { The institution offers various facilities to students who take } \\
\text { part in SR activities, regardless of the organiser }\end{array}$ & & 0.839 \\
\hline The institution rewards SR activities, regardless of organiser & & \\
\hline
\end{tabular}

$$
\text { Source: Authors' own contribution }
$$

A factorial analysis was then used in order to see the loadings of the various questions on each one of the scales as proposed by Gage and Thapa (2011). The analysis was conducted in $\mathrm{R}$ version 3.4.3. (table no. 2). The questions can be found on the first column, the factors on the first row on the loadings in the table. The scores were then extracted with using the maximum likelihood method.

Table no. 2: Factor loadings for motivation

\begin{tabular}{|l|c|c|c|c|c|}
\hline & Values & $\begin{array}{c}\text { Self- } \\
\text { protection }\end{array}$ & Social & Career & $\begin{array}{c}\text { Personal } \\
\text { enh. }\end{array}$ \\
\hline I feel it is important to help others & 0.584 & & & & \\
\hline $\begin{array}{l}\text { I am genuinely concerned about the } \\
\text { particular group I am serving }\end{array}$ & 0.511 & & & & \\
\hline $\begin{array}{l}\text { I am concerned with those less } \\
\text { fortunate than myself }\end{array}$ & 0.520 & & & & \\
\hline $\begin{array}{l}\text { SR activities allow me to gain a new } \\
\text { perspective on things }\end{array}$ & 0.727 & & & & \\
\hline $\begin{array}{l}\text { I can do something for a cause that is } \\
\text { important to me }\end{array}$ & 0.687 & & & & \\
\hline $\begin{array}{l}\text { I feel compassion toward people in } \\
\text { need }\end{array}$ & 0.647 & & & & \\
\hline I can explore my own strengths & 0.622 & & & & \\
\hline
\end{tabular}




\begin{tabular}{|c|c|c|c|c|c|}
\hline & Values & $\begin{array}{c}\text { Self- } \\
\text { protection }\end{array}$ & Social & Career & $\begin{array}{c}\text { Personal } \\
\text { enh. }\end{array}$ \\
\hline $\begin{array}{l}\text { I can learn how to deal with a variety } \\
\text { of people }\end{array}$ & 0.768 & & & & \\
\hline $\begin{array}{l}\text { I can learn more about the cause for } \\
\text { which I am working }\end{array}$ & 0.817 & & & & \\
\hline $\begin{array}{l}\text { SR activities lets me learn things } \\
\text { through direct, hands-on experience }\end{array}$ & 0.839 & & & & \\
\hline $\begin{array}{l}\text { Participating in SR activities is a way } \\
\text { for me to help the natural environment }\end{array}$ & 0.753 & & & & \\
\hline $\begin{array}{l}\text { Participating in SR activities is a good } \\
\text { escape from my own troubles }\end{array}$ & & 0.801 & & & \\
\hline $\begin{array}{l}\text { Participating in SR activities helps me } \\
\text { to work through my own personal } \\
\text { problems }\end{array}$ & & 0.764 & & & \\
\hline $\begin{array}{l}\text { By participating in SR activities, I feel } \\
\text { less lonely }\end{array}$ & & 0.780 & & & \\
\hline $\begin{array}{l}\text { Participating in SR activities makes me } \\
\text { feel needed }\end{array}$ & & 0.693 & & & \\
\hline $\begin{array}{l}\text { No matter how bad I've been feeling, } \\
\text { participating in SR activities helps me } \\
\text { to forget about it }\end{array}$ & & 0.819 & & & \\
\hline $\begin{array}{l}\text { Participating in SR work relieves me of } \\
\text { some of the guilt over being more } \\
\text { fortunate than others }\end{array}$ & & 0.750 & & & \\
\hline $\begin{array}{l}\text { People I'm close to want me to } \\
\text { participate in SR activities }\end{array}$ & & & 0.757 & & \\
\hline $\begin{array}{l}\text { Others with whom I am close place a } \\
\text { high value on community service }\end{array}$ & & & 0.828 & & \\
\hline My friends participate in SR activities & & & 0.768 & & \\
\hline $\begin{array}{l}\text { Participating in SR activities is an } \\
\text { important activity to the people I know } \\
\text { best }\end{array}$ & & & 0.881 & & \\
\hline $\begin{array}{l}\text { People I know share an interest in } \\
\text { community service }\end{array}$ & & & 0.870 & & \\
\hline $\begin{array}{l}\text { I feel like taking part in SR activities is } \\
\text { a religious duty }\end{array}$ & & & 0.589 & & \\
\hline $\begin{array}{l}\text { Participating in SR activities can help } \\
\text { me get a foot in the door at a place } \\
\text { where I would like to work }\end{array}$ & & & & 0.845 & \\
\hline $\begin{array}{l}\text { I can make new contacts that might } \\
\text { help my business or career }\end{array}$ & & & & 0.863 & \\
\hline $\begin{array}{l}\text { SR experiences will look good on my } \\
\text { resume }\end{array}$ & & & & 0.738 & \\
\hline $\begin{array}{l}\text { SR allows me to explore different } \\
\text { career options }\end{array}$ & & & & 0.818 & \\
\hline $\begin{array}{l}\text { Participating in SR activities will help } \\
\text { me to succeed in my chosen profession }\end{array}$ & & & & 0.774 & \\
\hline $\begin{array}{l}\text { Participating in SR activities is a way } \\
\text { to make new friends }\end{array}$ & & & & 0.626 & \\
\hline $\begin{array}{l}\text { Participating in SR activities makes me } \\
\text { feel important }\end{array}$ & & & & & 0.799 \\
\hline
\end{tabular}




\begin{tabular}{|l|l|l|l|l|c|}
\hline & Values & $\begin{array}{c}\text { Self- } \\
\text { protection }\end{array}$ & Social & Career & $\begin{array}{c}\text { Personal } \\
\text { enh. }\end{array}$ \\
\hline $\begin{array}{l}\text { Participating in SR activities increases } \\
\text { my self-esteem }\end{array}$ & & & & & 0.965 \\
\hline $\begin{array}{l}\text { Participating in SR activities makes me } \\
\text { feel better about myself }\end{array}$ & & & & 0.913 \\
\hline
\end{tabular}

Source: Authors' own contribution

In order to measure the constraints which might influence the decision making process of the individual on whether they should take part in SR types of activities, a similar analysis was conducted (table no. 3 ), the scores are extracted using a maximum likelihood.

Table no. 3: Factor loadings for constraints

\begin{tabular}{|l|c|c|c|}
\hline & Structural & Interpersonal & Intrapersonal \\
\hline I have no time to take part in SR activities & 0.734 & & \\
\hline I have too many other commitments & 0.829 & & \\
\hline I have a limited budget & 0.694 & & \\
\hline $\begin{array}{l}\text { I am unaware of opportunities to participate in SR } \\
\text { activities }\end{array}$ & 0.688 & & \\
\hline I do not have transportation to SR activity sites & 0.581 & & \\
\hline My friends do not participate in SR activities & & 0.635 & \\
\hline $\begin{array}{l}\text { I do not know anyone that participates in SR } \\
\text { activities }\end{array}$ & & 0.774 & \\
\hline I have no one to work with in SR activities & & 0.862 & \\
\hline No one has asked me to participate in SR activities & & 0.818 & \\
\hline My family does not take part in SR activities & & 0.685 & \\
\hline I have an injury, handicap, or ill health & & & 0.771 \\
\hline I do not have the necessary skills & & & 0.851 \\
\hline I do not feel safe at SR activity sites & & & 0.864 \\
\hline I think it will negatively affect my grades & & & 0.704 \\
\hline $\begin{array}{l}\text { I do not have enough energy to take part in SR } \\
\text { activities }\end{array}$ & & & \\
\hline
\end{tabular}

Source: Authors' own contribution

The next step, after finding the values for the various scales, was to see how they correlated with each other and if there were any links of interest which should be analysed in greater depth (table no. 4).

Table no. 4: Correlation matrix

\begin{tabular}{|c|c|c|c|c|c|}
\hline & $\begin{array}{c}\text { Structural } \\
\text { barriers }\end{array}$ & $\begin{array}{c}\text { Interpersonal } \\
\text { barriers }\end{array}$ & $\begin{array}{c}\text { Intrapersonal } \\
\text { barriers }\end{array}$ & $\begin{array}{c}\text { University } \\
\text { values }\end{array}$ & $\begin{array}{c}\text { University } \\
\text { opportunities }\end{array}$ \\
\hline Values & -0.016 & -0.107 & -0.140 & 0.345 & 0.290 \\
\hline Self-protection & 0.176 & 0.098 & 0.189 & 0.367 & 0.372 \\
\hline Social & 0.301 & 0.203 & 0.378 & 0.383 & 0.394 \\
\hline Career & 0.170 & 0.067 & 0.138 & 0.405 & 0.424 \\
\hline Enhancement & 0.236 & 0.174 & 0.253 & 0.348 & 0.311 \\
\hline \multicolumn{5}{r}{ Source: Authors' own contribution } \\
\end{tabular}

The results are somewhat surprising, but they might account for the large number of people who do not take part in SR activities. It is interesting to note that the results for social and enhancement are correlated with the various barriers. This information, taken together with 
the rest of the analysis going forward, is interesting as it might account for those people who might have a social or personal enhancement motivation to participate yet they might be discouraged by the way in which they perceive barriers.

It is interesting to note that the factors measuring the activity of the university are highly correlated with all the motivators. This result would seem to show that the students might try to emulate the values demonstrated by the university where they are enrolled. In a similar fashion for the scale measuring opportunities, they are highly correlated with motivators, pointing towards a similar conclusion.

Next, the authors tested if there are significant differences in the motivation or the manner in which they perceive the barriers they might encounter between those who did partake in SR activities and those who did not. The data is split between those that have done this in the last year or during high-school. A $t$ test was conducted, with the null hypothesis being that the mean scores are equal between those who did and did take part in SR activities. (table no. 5) contains the $p$-values for the null hypothesis for each one of these differences.

Table no. 5: Differences in scores for participants in SR activities

\begin{tabular}{|l|c|c|}
\hline & Last 12 months (p-value) & High-school (p-value) \\
\hline Values & $6.327 \times 10^{-5}$ & 0.002 \\
\hline Self-protection & 0.041 & 0.713 \\
\hline Social & 0.257 & 0.665 \\
\hline Career & 0.037 & 0.683 \\
\hline Enhancement & 0.273 & 0.273 \\
\hline Structural barriers & $1.699 \times 10^{-5}$ & $8.25 \times 10^{-6}$ \\
\hline Interpersonal barriers & $1.927 \times 10^{-7}$ & $5.74 \times 10^{-5}$ \\
\hline Intrapersonal barriers & 0.002 & 0.013 \\
\hline \multicolumn{2}{|c|}{ Source: Authors'own contribution } \\
\hline
\end{tabular}

The results of the test for the last 12 months show that there are significant differences between the ones who did and did not take part in SR activities in terms of the scales for values, self-protection and career. Furthermore, all the barriers were identified to be significant, with the values being smaller for those who did take part in SR activities than those who did not, which would mean that they had fewer barriers or were less influenced by them in their decision making process.

In high-school the emphasis seems to be less on the self-protection or career aspects, which would indicate that, as they age, they would immerse themselves more in such SR activities later on in order to improve their own wellbeing or to better prepare for their future career. The main motivation, in high-school, seems to be drawn from the values they exhibit. In this case all the barriers are significant, with the scores being lower for those who did participate in SR activities which would lead to a similar conclusion, either they had fewer barriers or they were less important to them.

This initial analysis took into consideration each variable on its own and showed values, self-protection and career as well as all the barriers to be significant. A better view can be obtained by constructing a binary logit model using participation in SR activities as a dependent variable $(0-$ No, 1 - Yes $)$ and the scales for values, self-protection, social career, enhancement, structural barriers, interpersonal barriers, intrapersonal barriers as independent variables. The control variables taken into consideration are gender, year of study, size of town or city of origin and employment status. 
From the results, we can see there is a significant overlap and the independent variables are highly collinear. Due to this issue, the authors excluded university values and opportunities from the model at first because the high overlap between them and the rest of the scales and are studied separately. Even so, some of the variables continued to be correlated. In order to obtain the best model, the Akaike information criterion was used in order to eliminate statistically insignificant variables. Table no. 6 contains only the significant variables.

Table no. 6: Binary logit regression for motivation and demotivation factors

\begin{tabular}{|c|c|c|c|c|}
\hline & \multicolumn{4}{|c|}{ Dependent variable: Involvement in SR activities } \\
\hline & \multicolumn{2}{|c|}{ Last 12 months (1) } & \multicolumn{2}{|c|}{ High-school (2) } \\
\hline & $\begin{array}{l}\text { Coefficient } \\
\text { value }\end{array}$ & $\begin{array}{l}\text { Standard } \\
\text { error }\end{array}$ & $\begin{array}{l}\text { Coefficient } \\
\text { value }\end{array}$ & $\begin{array}{l}\text { Standard } \\
\text { error }\end{array}$ \\
\hline Values & $0.299 * *$ & $(0.145)$ & $0.398 * * *$ & $(0.117)$ \\
\hline Social & $0.313 * *$ & $(0.140)$ & & \\
\hline Structural barriers & $-0.438 * * *$ & $(0.152)$ & $-0.532 * * *$ & $(0.124)$ \\
\hline Interpersonal barriers & $-0.410 * * *$ & $(0.151)$ & & \\
\hline $\begin{array}{l}\text { Specialization: Business Administration (in } \\
\text { Romanian) }\end{array}$ & 0.385 & $(0.298)$ & 0.390 & $(0.268)$ \\
\hline Specialization: Marketing & 0.158 & $(0.342)$ & $0.678 * *$ & $(0.305)$ \\
\hline $\begin{array}{l}\text { Specialization: Business Administration (in } \\
\text { English) }\end{array}$ & $1.586 * * *$ & $(0.455)$ & $1.390 * * *$ & $(0.487)$ \\
\hline Specialization: Cybernetics & 0.192 & $(0.534)$ & $0.865 *$ & $(0.503)$ \\
\hline Year of Study: 2 & $-0.553 * *$ & $(0.280)$ & & \\
\hline Year of Study: 3 & $-1.004 * * *$ & $(0.310)$ & & \\
\hline Constant & $-0.653 * *$ & $(0.260)$ & -0.063 & $(0.190)$ \\
\hline Observations & \multicolumn{2}{|c|}{396} & \multicolumn{2}{|c|}{388} \\
\hline Log Likelihood & \multicolumn{2}{|c|}{-216.899} & \multicolumn{2}{|c|}{-242.896} \\
\hline Akaike Inf. Crit. & \multicolumn{2}{|c|}{455.799} & \multicolumn{2}{|c|}{499.792} \\
\hline
\end{tabular}

It can be seen from model (1) that personal values are significant and can have an effect on the individual by leading to an increase in the odds of someone participating in SR activities. The social environment has a significant impact during time at the university, but not during high-school when other factors are more important. On the other hand, structural and interpersonal barriers have a significant and negative impact as well. Therefore, they decrease the odds that someone might be interested in taking part in these types of activities. Similar results can be found in model (2) which refers to participation in SR activities during high-school. It is interesting to note that students in higher years of study are less interested in these types of activities.

These results are significant as they show that improving involvement in SR activities can be approached in two ways. First would be to foster values relating to SR in the individual which can increase their level of interest, this can be done either through various courses or students' activities, as shown by other studies (Ahmad, 2012; Waas et al., 2012). The second would be the removal of barriers that they might encounter in the process because this would contribute to the sustainable development of the university (Menegat and Sarmento, 2018; Filho et al., 2019).

The analysis is completed with a second binary logit analysis, this time only taking into consideration the institutional scales. The same control variables were accounted for and 
the Akaike information criterion was again used to select the significant variables. Only the significant variables are presented in table no. 7 .

Table no. 7: Binary logit regression for institutional scales

\begin{tabular}{|l|c|c|}
\hline & \multicolumn{2}{|c|}{$\begin{array}{c}\text { Dependent variable: Involvement in SR } \\
\text { activities in the last 12 months }\end{array}$} \\
\hline & Coefficient value & Standard error \\
\hline University values & $0.245^{*}$ & 0.132 \\
\hline University opportunities & $-0.231^{*}$ & 0.133 \\
\hline $\begin{array}{l}\text { Specialization: Business Administration } \\
\text { (in Romanian) }\end{array}$ & $0.465^{*}$ & 0.281 \\
\hline Specialization: Marketing & -0.026 & 0.324 \\
\hline $\begin{array}{l}\text { Specialization: Business Administration } \\
\text { (in English) }\end{array}$ & $1.599^{* * *}$ & 0.439 \\
\hline Specialization: Cybernetics & & 0.501 \\
\hline Year of Study: 2 & $-0.598^{* *}$ & 0.266 \\
\hline Year of Study: 3 & $-1.139 * * *$ & 0.298 \\
\hline Constant & $-0.494^{* *}$ & 0.245 \\
\hline Observations & 396 & \\
\hline Log Likelihood & -233.770 & \\
\hline Akaike Inf. Crit. & 485.539 & \\
\hline \multicolumn{2}{|c|}{ Note: $* \mathrm{p}^{* *} \mathrm{p}^{* * *} \mathrm{p}<0,01$} & \\
\hline
\end{tabular}

We can notice that all the variables in this model are significant. However, the results are somewhat surprising with regard to the opportunities because they would seem to have a negative impact, which would mean that increasing the number of opportunities to participate in SR activities would lead to lower odds for students to actually take part in them. The only possible explanation might be that they are not interested in the opportunities they receive and are less interested in volunteer activities. With regard to the university values exhibited, the result is as expected, should the institution exhibit the values promised and promote SR activities, it can lead to an increase in the odds for students to volunteer for them, which validates previous results (Sousa et al., 2020). For this reason, the university should always improve and diversify its offer of SR activities and encourage student participation (Al-Khoury et al., 2015).

\section{Conclusions}

This paper contributes to the enrichment of the literature related to sustainability in HE. From a theoretical point of view, it provides some clarifications regarding the concepts of sustainability and SR. Moreover, the paper explains the relationship between the two concepts in HE, emphasizing that both are concentrating on the same dimensions (economic, social, and environmental). It also shows that the SR activities lead to the development of sustainable HEIs through the active engagement and participation of their stakeholders (e.g., students, professors).

From a practical point of view, sustainability and SR are intertwined and should be a priority for any HEI. The integration of sustainability in the activities, processes and strategies of HEIs cannot ignore its social dimension. This paper aims to highlight the most important motivational factors that can cause students to participate in SR activities. The 
factorial analysis of the gathered data identified five factors that contribute to engaging in SR activities: values, self-protection, social, career, and personal enhancement, and three types of barriers: structural, interpersonal and intrapersonal. In turn, the binary logit model demonstrated that personal values and social environment are the main motivators of students and these should be at the centre of any institutional strategy that wants to increase the participation rate in RS activities. This result is further supported by the second model that showed that institutional values also have a positive impact and can lead to higher participation rates, and the development of a sustainable HEI. Moreover, the structural and interpersonal barriers represent the main impediments and should be eliminated if an improvement of the results is desired. Therefore, the decision makers from HEIs together with the most important stakeholders, especially students and professors, could analyse the outcomes of this study and remove some of the barriers that may prevent universities from developing in a sustainable manner. The co-interest of other stakeholders can be a difficult task at the institutional level, and the way in which it is accomplished may be different, depending on the objectives of the HEIs, and may be the subject of future researches.

An unexpected result is the negative relationship between the opportunities provided by the HEIs and the students' willingness to take part in SR activities. One possible explanation is the mismatch between the opportunities offered and the desires of students. However, the dilemma remains and may constitute a future research direction. It is also surprising that the year of study has a negative impact on the likelihood of getting involved in a SR activity, and free time does not seem to be a limiting factor because the employee status is not statistically relevant. Thus, a future research could determine the reason why the degree of involvement of the students from higher years of study decreases.

A limitation of the research is given by the way in which all types of SR activities are taken together. Some SR activities may be more attractive to a particular student profile or may present more significant barriers than others. The current study does not address this topic and it is a possible direction for future research. A second limitation of the study is the size and structure of the sample. It is representative at the faculty level, but it is difficult to generalize these results to other faculties in Romania or abroad. A larger and more representative sample should be taken into account in the future. A third limitation is given by the reduced ability to propose solutions. The study identified several important factors and barriers, but these are not determined precisely enough in order to allow the formulation of practical solutions.

\section{References}

Agostino, D. and Dal Molin, M., 2016. A grid approach to managing sustainability: evidence from a multiple Italian case study. International Journal of Sustainability in Higher Education, 17(6), pp.875-894.

Ahmad, J., 2012. Can a university act as a corporate social responsibility (CSR) driver? An analysis. Social Responsibility Journal, 8(1), pp.77-86.

Al-Khoury, P., Bolkart, K., Fechter, I. and AlShamali, M., 2015. Students social responsibility initiatives and impact on university performance: an empirical study from Lebanon. Business Education \& Accreditation, 7(2), pp.75-87. 
Amaral, L.P., Martins, N. and Gouveia, J.B., 2015. Quest for a sustainable university: a review. International Journal of Sustainability in Higher Education, 16(2), pp.155-172.

Arroyo, P., 2015. A new taxonomy for examining the multi-role of campus sustainability assessments in organizational change. Journal of Cleaner Production, 140(3), pp.1763-1774.

Barth, M., Michelsen, G., Rieckmann, M. and Thomas, I., 2016. Routledge Handbook of Higher Education for Sustainable Development. New York: Routledge.

Collins, D. and Gannon, A., 2014. Walking the eco-talk movement: Higher education institutions as sustainability incubators. Organization \& Environment, 27(1), pp.16-24.

Cortese, A.D., 2003. The critical role of higher education in creating a sustainable future. Planning for Higher Education, 31(3), pp.15-22.

Dabija, D.C., Dinu, V., Postelnicu, C., Mihăilă, A., 2017. Stakeholders' perception of sustainability orientation within a major Romanian university. International Journal of Sustainability in Higher Education, 18(4), pp.533-553.

Dinu, V., 2011. Corporate social responsibility- opportunity for reconciliation between economical interests and social and environmental interests. Amfiteatru Economic, 13(29), pp.6-7.

Filho, W.L., Doni, F., Vargas, V.R., Wall, T., Hindley, A., Rayman-Bacchus, L., EmblenPerry, K., Boddy, J. and Avila, L.V., 2019. The integration of social responsibility and sustainability in practice: exploring attitudes and practices in higher education institutions. Journal of Cleaner Production, 220, pp.152-166.

Gage, R. and Thapa, B., 2011. Volunteer motivations and constraints among college students: analysis of the volunteer function inventory and leisure constraints models. Nonprofit and Voluntary Sector Quarterly, 41(3), pp.405-430.

Hopwood, B., Mellor, M. and O’Brien, G., 2005. Sustainable development: Mapping different approaches. Sustainable Development, 13(1), pp.38-52.

International Institute for Sustainable Development (IISD), 2004. Perceptions and Definitions of Social Responsibility. [online] Available at: <http://inni.pacinst.org/ inni/corporate_social_responsibility/standards_definitions.pdf $>$ [Accessed 14 September 2019].

International Standard Organization (ISO), 2010. ISO 26000- Guidance on Social Responsibility, Clause 2.18. Geneva: ISO.

International Union for the Conservation of Nature and Natural Resources (IUCN), United Nations Environment Programme (UNEP) and World Wildlife Fund (WWF), 1980. World Conservation Strategy: Living Resource Conservation for Sustainable Development. [online] Available at: <https://portals.iucn.org/library/sites/library/ files/documents/WCS-004.pdf> [Accessed 12 December 2019].

Ismail, T.H., 2019. Does Egyptian universities' disclosure on social responsibility enhance sustainable development? [online] Available at: < https://doi.org/10.1108/JHASS-082019-0042> [Accessed 03 March 2020]. 
Jardim, C. and da Silva, S.M., 2018. Young people engaging in volunteering: questioning a generational trend in an individualized society. Societies, 8(1), pp.1-11.

Marrone, P., Orsini, F., Asdrubali, F. and Guattari, C., 2018. Environmental performance of universities: Proposal for implemeneting campus urban morphology as an evaluation parameter in Green Metric. Sustainable Cities and Society, 42, pp.226-239.

Menegat, J. and Sarmento, D. F., 2018. Educating for social responsibility: a commitment of Lasallian higher education institutions. Conhecimento \& Diversidade, 10(22), pp.42-53.

Montiel, I. and Delgado-Ceballos, J., 2014. Defining and measuring corporate sustainability: Are we there yet? Organization \& Environment, 27(2), pp.113-139.

Peloza, J., Loock, M., Cerruti, J. and Muyot, M., 1976. Sustainability: How stakeholder perceptions differ from corporate reality. California Management Review, 55(1), pp.74-97.

Robinson, J., 2004. Squaring the circle? Some thoughts on the idea of sustainable development. Ecological Economics, 48(4), pp.369-384.

Roosevelt, A.E., 2008. Good citizenship: The purpose of education. Yearbook of the National Society for the Study of Education, 107(2), pp.312-320.

Salvioni, D.M., Franzoni, S. and Cassano, R., 2017. Sustainability in the higher education system: an opportunity to improve quality and image. Sustainability, 9(6), pp.1-27.

Sharma, S. and Hart, S.L., 2014. Beyond "saddle bag" sustainability for business education. Organization \& Environment, 27(1), pp.10-15.

da Silva Junior, A., Martins-Silva, P. de O., Vasconcelos, K.C. de A., Silva, V.C., Brito, S.L.M.S. and Monteiro, J.M.R., 2019. Sustainability and corporate social responsibility in the opinion of undergraduate students in management programs: Between the concrete and the abstract. Journal of Cleaner Production, 207(1), pp.600-617.

Simmons, T., 1986. The bridge builder in quest for community. In: M. Darrol Bryant and H.R. Huessy (eds.), 1986. Eugen Rosenstock-Huessy: Studies in His Life and Thought. Lewiston: The Edwin Mellen Press. pp.131-144.

Sloane, G.M.T. and Probstl-Haider, U., 2019, Motivation for environmental volunteering A comparison between Austria and Great Britain, Journal of Outdoor Recreation and Tourism-Research Planning and Management, 25, pp.158-168.

Sousa, J., Siqueira, E., Binotto, E. and Nobre, L., 2020. University social responsibility: perceptions and advances. [online] Available at: <https://doi.org/10.1108/SRJ-10-20170199> [Accessed 03 March 2020].

Strauss, V., 2015. What's the purpose of education in the 21st century? The Washington Post, 12.02.2015. [online] Available at: <https://www.washingtonpost.com/ news/answer-sheet/wp/2015/02/12/whats-the-purpose-of-education-in-the-21stcentury/> [Accessed 22 December 2019]. 
Székely, F. and Knirsch, M., 2005. Responsible leadership and corporate social responsibility: Metrics for sustainable performance. European Management Journal, 23(6), pp.628-647.

Su, J.H. and Chang, T., 2010. Sustainability of higher education institutions in Taiwan. International Journal of Sustainability in Higher Education, 11(2), pp.163-172.

Toma, S.G., 2008. Social responsibility and corporate citizenship in the 21th century. Amfiteatru Economic, 23(10), pp.80-85.

Toma, S.G. and Grădinaru, C., 2018. Responsible management for sustainable development: a Japanese approach. Annals of the „Constantin Brâncuşi” University of Târgu Jiu, Economy Series, 3, pp.149-154.

United Nations (UN), 2015. Transforming our world: the 2030 Agenda for Sustainable Development. General Assembly, 21.10.2015. [online] Available at: <https://www.un.org/ga/search/view_doc.asp?symbol=A/RES/70/1\&Lang=E> [Accessed 10 December 2019].

Vargas, L., Mac-Lean, C. and Huge, J., 2019. The maturation process of incorporating sustainability in universities. International Journal of Sustainability in Higher Education, 20(3), pp.441-451.

Velazquez, L., Munguia, N., Platt, A. and Taddei, J., 2006. Sustainable university: what can be the matter? Journal of Cleaner Production, 14(9/11), pp.810-819.

Waas, T., Hugé, J., Ceulemans, K., Lambrechts, W., Vandenabeele, J., Lozano, R. and Wright, T., 2012. Sustainable Higher Education-Understanding and Moving Forward. Brussels: Flemish Government -Environment, Nature and Energy Department. [online] Available at: <https://www.vub.be/klimostoolkit/sites/default/files/documents/sustainable_higher_ed ucation_understanding_and_moving_forward_waas_et_al_.pdf $>$ [Accessed 14 December 2019].

Wanamaker, C., 2018. The environmental, economic, and social components of sustainability. Soapboxie, 24.04.2018. [online] Available at: <https://soapboxie.com/ social-issues/The-Environmental-Economic-and-Social-Components-of-Sustainability> [Accessed 14 December 2019].

Whitley, C.T. and Yoder, S.D., 2015. Developing social responsibility and political engagement: Assessing the aggregate impacts of university civic engagement on associated attitudes and behaviors. Education Citizenship and Social Justice, 10(3), pp. 217-233.

World Commission on Environment and Development, 1987. Our Common Future. Oxford: Oxford University Press.

Wright, T.S.A., 2007. Developing research priorities with a cohort of higher education for sustainability experts. International Journal of Sustainability in Higher Education, 8(1), pp.34-43.

Wright, T., 2010. University presidents' conceptualizations of sustainability in higher education. International Journal of Sustainability in Higher Education, 11(1), pp.61-73. 